\title{
Open Business Models for the Greater Good - A Case Study from the Higher Education Context
}

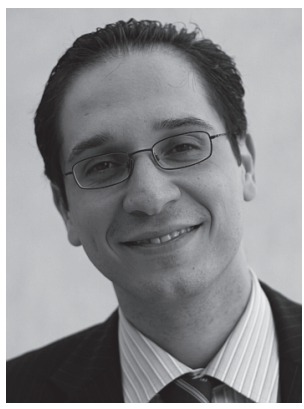
Geld verdienen. Im engeren Sinn beschreibt ein Geschäftsmodell die Mechanismen der Kommunikation, Erzeugung, Lieferung und Einnahme des Wertes eines Wertangebotes. Innerhalb dieses Beitrages wird das Geschäftsmodell-Konzept vorgestellt, welches als dritte Komponente eingesetzt wird, um den Prozess von Open Innovation mit dem Ziel der Steigerung des Allgemeinwohls (greater good) zu stärken. In diesem Kontext wird greater good als das Ergebnis von Innovationen für die Allgemeinheit und sozialen Innovationen definiert. Basierend auf zwei Dimensionen, Wert-Angebot und Wert-Einnahme, werden in diesem Beitrag vier Kategorien von Geschäftsmodellen identifiziert, welche bedeutendes Potenzial besitzen, das Wohlergehen einer Gesellschaft und der Menschheit insgesamt zu verbessern. Um die Ideen dieses Beitrages exemplarisch zu illustrieren, wird ein Beispiel aus dem Hochschulwesen betrachtet. Das Modell der Open School ist ein Geschäftsmodell von Universitäten, bei dem Open-Innovation-Prozesse und Werkzeuge zugunsten des Allgemeinwohls eingesetzt werden. Ein bedeutendes Merkmal dieses Modells ist, dass Studierende nicht länger passive Konsumenten von Wissen und Forschung sind, sondern aktive Teilnehmer in der Produktion von Wissen und Innovationen.

Open innovation for the greater good cannot happen until innovative business models are implemented. Very simply, a business model refers to the way companies are making money or the logic of doing business. More concretely, a business model denotes the bunch of mechanisms that show how companies are communicating, creating, delivering, and capturing value out of a value proposition. Thus, this paper introduces the business model concept, as a third component that leverages the process of open innovation to achieve the greater good. The greater good is defined in this paper as the outcome of innovations for the commons and social innovations. Based on two dimensions: value proposition and value capture, the paper identifies four business model categories that have high potential to improve the well-being of society, and humanity at large. To illustrate the ideas of this paper with an example from practice, higher education is taken as a context. The open school is a university business model that uses open innovation processes and tools for the benefit of the greater good. One important characteristic of this business model is that stu- 
dents are no longer the passive consumers of knowledge and research, but are active participants in the production of knowledge and innovations.

\section{Introduction}

In recent years, the discussion on openness has increasingly intensified. Inspired by open innovation (Chesbrough 2003; Chesbrough et al. 2006), companies are realizing the importance of opening their processes to the external world. In fact, the open innovation paradigm fundamentally recommends opening the innovation process to ideas from the outside. But in principle openness can be applicable to any process within the company.

Reichwald/Piller (2009) consider a broader view of openness and introduce a more comprehensive concept, which they refer to as interactive value creation. They define the term as a combination of two concepts: open innovation, which is based on interactions with external sources during the innovation and R\&D processes, and mass customization, which enables external sources to be involved in the production process. In mass customization, customers are considered prosumers (Toffler 1980); they are provided with suitable tools to specify their requirements and to select their individual product configurations out of a large solution space.

In this paper, openness means that individuals or organizations look proactively for good ideas from the outside world that can have an impact on any area of the company. To identify these areas, the business model concept delivers a very suitable framework, as it goes beyond innovation and production processes to provide a holistic view of the company. Recently, business models have been very intensively discussed in management literature. In general terms, a business model denotes the way of doing business, and how companies make their money.

Meanwhile, openness is becoming a principle that is influencing very strongly our personal lives. In social networks, people are revealing more and more information about themselves; they are providing access to information that was considered in the past to be part of the private sphere. In addition, individuals and organizations are using openness to generate innovations for the greater good. Innovations for the greater good can be defined as innovations that benefit society and humanity at large.

The main thesis of this paper is that in order for institutions, organizations or individual persons to leverage the advantages of openness, they need adequate business models. In other words, the business model concept represents a coherent and adequate framework to study how the principle of openness can be used to serve the greater good. To achieve this objective, the paper is organized as follows. In the next section, I review the literature on business models and propose a comprehensive business model framework. Subsequently, I establish the link between openness and business models, and define the term open business models. In section three, I argue that business models represent important mediators between open innovation and the greater good. In addition, a taxonomy that distinguishes four categories of business models for the greater good is introduced. Section four provides a case example from the higher education context. In this section, I describe the basic idea of an innovative business model called open school that leverages the principles of openness to provide benefits for the greater good. Finally, section five summarizes the findings of this paper, discusses the main results, and identifies possible directions for future research. 


\section{Business Models and Open Business Models}

\subsection{Business Models}

Recently, the discussion of the business model concept has dramatically intensified. In the management literature (e.g. Osterwalder/Pigneur 2010), a business model denotes an integrative concept that combines all the relevant fields of the company in a meaningful way. A business model shows the logic how the company performs (e.g. Magretta 2002). Furthermore, it is neither strategy, nor operations. A strategy defines the long term objectives of the company; it serves as a guidance that supports managers in selecting an adequate business model out of alternative options. Thus a business model describes how the strategy is to be achieved, given certain environmental constraints. Operations describe the implementation of the business model, as experienced in the real world. Whereas not all of the companies have strategies, all companies have business models and operations (Casadesus-Masanell/Ricart 2010).

A business model is, first of all, a model. A model is an adequate representation of reality, which is not necessarily a one-to-one description of the real world. To capture the real world, one should examine the company's operations; in other words, its daily business. Thus, the business model is the representation of that reality; it abstracts the complexity in operations and captures the essential mechanisms, according to which business is conducted, without going into the details of operations.

In the business model literature, there is still a big debate on the dimensions that define a business model. Many definitions and interpretations of the business model concept are available, making it very hard to operationalize the construct without ambiguity. In the following, I will not provide a detailed overview of the literature, which dealt with business model frameworks; I just deal with some selected definitions and then present our framework.

For instance, Lecocq et al. (2006) define a business model as the interplay between three dimensions: value proposition, value network, and resources and competencies. The value proposition describes what the company offers to the market. The value network is related to the company's internal organization and especially to its transactions with external partners. Finally, the competencies and resources should be leveraged to create value to the customer. Surprisingly, Lecocq et al. (2006) did not include a dimension that has been widely accepted in the management literature, as an important component for the description of business models. It is the dimension that deals with how companies make money out of their business, in other words how they capture value.

Another framework with a good acceptance in management literature is the business model representation of Johnson (2010). As opposed to Lecocq et al. (2006), Johnson does not consider the value network perspective, but introduces the profit formula and key process dimension into his business model framework. Johnson defines a business model as the interaction between four dimensions: value proposition (the set of products and services offered to the customers), profit formula, which consists of the revenue model and cost structure, key processes and key resources. In Johnson's representation, value proposition and profit formula designate dimensions that can be identified without ambiguity, whereas the choice of the key processes and resources depends on the company's case and needs some deal of interpretation. 
In comparison to Lecocq et al. (2006) and Johnson (2010), Osterwalder/Pigneur (2010) develop a more comprehensive framework. They introduce the so-called business model canvas, which consists of nine dimensions: customer segments, value propositions, channels, customer relationships, revenue streams, key resources, key activities, key partnerships, and cost structure. This representation has a wide implementation in practice and supports teams to develop business models for their companies in interactive workshop sessions.

In this paper, however, I argue that a business model denotes a concept that principally deals with value. The ultimate objective of businesses is to produce value for the customer in order to generate value for themselves, because a company that does not create value for itself cannot survive. Since business models describe an abstract representation of the company's operations, it is obvious that good business models may not be successful, if they are not implemented adequately. Inefficiencies at the operational level can lead to value destruction, resulting in the fact that good business models can fail to achieve their objectives.

I define a business model as the way a company communicates, creates, delivers, and captures value out of a value proposition. The value proposition is at the center of the business model, whereas value communication, creation, delivery and capture are placed around. The framework shows that in order for companies or even individuals to come up with innovative business models, innovations can take place at the level of each of these five dimensions. Abdelkafi et al. (2012) show that the business model patterns, suggested so far in literature, generally focus on a single dimension of the framework presented above. Thus, an appropriate combination of these patterns can deliver innovative business models.

Value proposition denotes "an overall view of a company's bundle of products and services that are of value to the customer" (Osterwalder 2004, 43). Similarly, Johnson (2010) describes value proposition as an offering that addresses the job-to-be-done and satisfies customers' needs whether they know it or not. Value creation is the result of a resource transformation. Resources are tangible (e.g. production facilities, materials, money etc.) and intangible (e.g. knowledge, reputation etc.) goods, which are transformed to a product or service (Huff et al. 2008). Value communication ensures the delivery of value proposition as a message to the target groups, such as customers, investors etc. Since different target groups require different information, value proposition has to be conveyed by a story which should be understandable, catchy and coherent. To whom the value proposition is addressed and how it is distributed describes the value delivery. It defines the means by which enterprises establish interactions with the customer in order to provide the value proposition (Bieger/Reinhold 2011). Value capture describes how the value proposition is transformed into revenue a stream and then captured as profit. Value capture depends on the cost structure, which includes "direct costs and overhead, taking into account economies of scale" (Johnson 2010, 36). The revenue stream is the product of the offering price and the quantity of sold goods. The difference between the revenue stream and costs represents the enterprise's profit. 


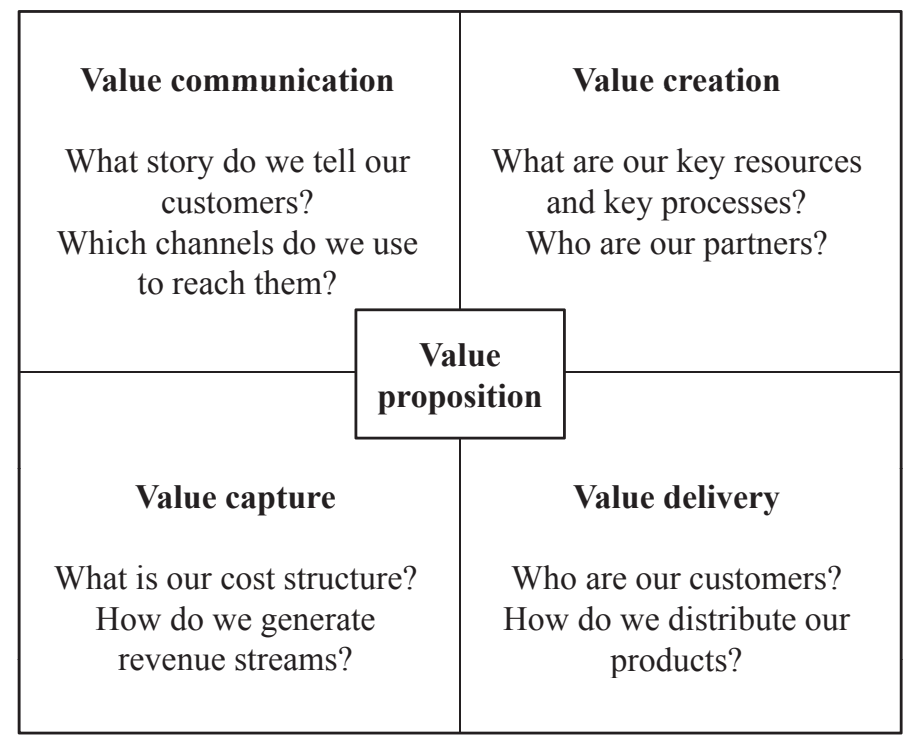

Figure 1: Business model framework

\subsection{Open Business Models}

The concept of open business models has been introduced by Chesbrough (2006). According to him, open business models result from the application of the open innovation paradigm. In line with Chesbrough's understanding, it is possible to use the above framework to define open business models. For business models to be called open, they have to reveal some openness with respect to at least one of the value dimensions identified above: value proposition, communication, creation, delivery, or capture. These dimensions of value are open, if they can be impacted by external contributors. For instance, in many communitydriven projects, companies or individuals may start with very rough specifications of a value proposition for a possible product or software. Thus the value proposition is unknown at the very early stages of the project. Subsequently, the community built around the corresponding project, starts discussing and developing the value proposition that will be ultimately offered to the final customer (Abdelkafi et al. 2010). Value communication can also be open, when companies use network effects or involve single persons or communities that support the diffusion of their offers. Unilever in India leverages new influencers to deliver cosmetic products to a local female clientele (Johnson 2010). Spreadshirt involved its community differently in value communication; it initiated a competition in order to let the community develop the company's logo (Reichwald/Piller 2009). For value creation, many examples show how customers or users can be involved into the process. Value cocreation means that customers, users or other stakeholders contribute into the process of producing value (Ramaswamy/Gouillart 2010). For instance, Threadless gives its customers the possibility to co-design their T-shirts (Howe 2008). Chip manufacturers may provide their customers with the opportunity to co-design and simulate the functioning of integrated circuits before placing their final orders (von Hippel 2005). Value delivery can also be open, as users, customers, or developers can co-deliver value. For example, in the 
RepRap project, the 3D printer project initiated by the University of Bath, every participant in the project who owns a 3D printer can act as component suppliers, delivering value to those who require printer parts (Abdelkafi et al. 2010). Amazon's marketplace or Ebay also represent open business models, in the sense that every seller directly sells goods to buyers. The open source software movement represents an excellent example how value can be delivered by independent programmers geographically distributed in many regions worldwide (von Hippel/von Krogh 2003). Finally, value capture can also be influenced by external contributors. For example, Apple introduced a multi-sided platform, in which programmers can upload their apps and make money out of them. The more money the app programmers makes, the larger the profits that Apple can achieve (Osterwalder/ Pigneur 2010).

\section{Open Business Models for the Greater Good}

The business model framework provides a powerful tool to fully leverage the potentials of open innovation. Within this framework, openness seems to be a principle that may not only affect the products and services offered to the customers (value proposition), but also other business model dimensions. Thus, companies miss a big opportunity, if they only use external ideas and technologies to generate new products and services. Consequently, the business model framework enables us to have a more comprehensive view of all areas in which open innovation can take place (Figure 2). In the following, I will propose a taxonomy that is useful for the classification of open business models for the greater good. This taxonomy, however, combines only two dimensions from the business model framework: the value proposition and value capture. This reduces the complexity of the classification scheme, but still captures the main categories of business models for the greater good.

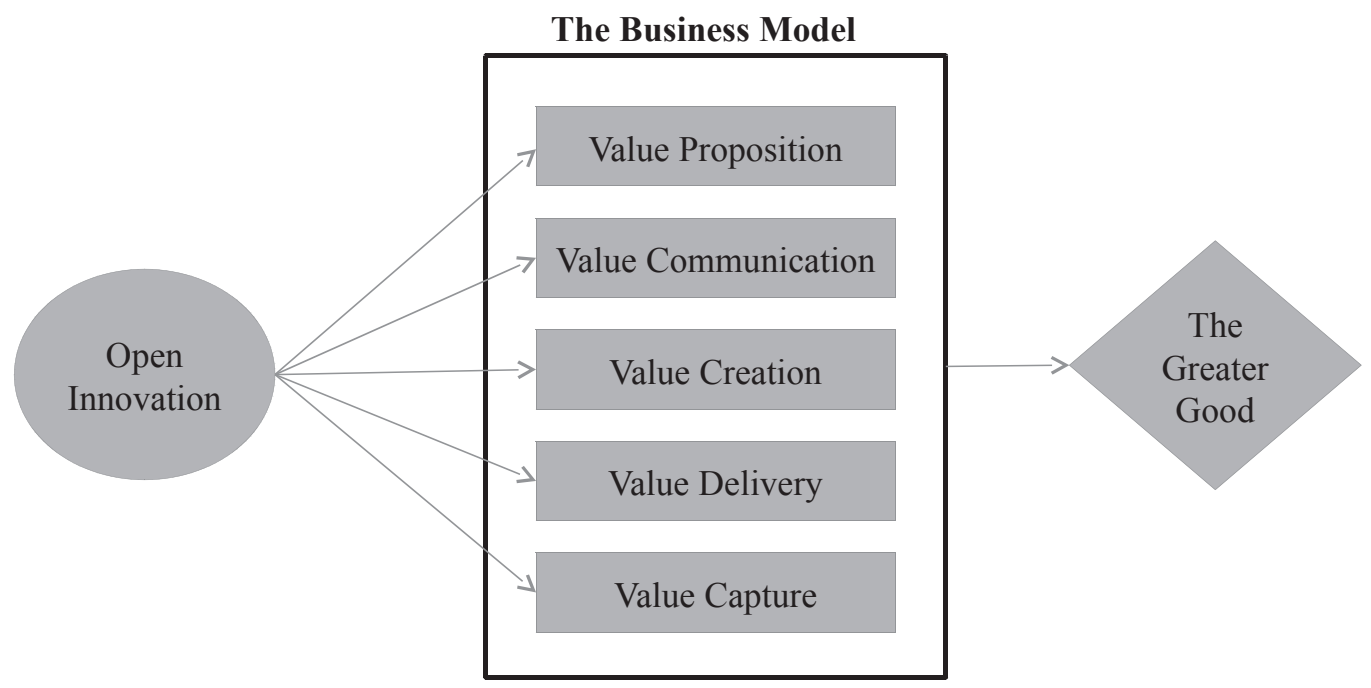

Figure 2: The business model as a mediator for leveraging open innovation for the greater good 


\subsection{The Value Proposition in Business Models for the Greater Good}

Innovation for the greater good can be thought of as a concept that is related to social innovations. In effect, all what is social can be thought to be contributing to the greater good. Ross et al. (2012) note that social innovation has been a growing phenomenon in the last 20 years and has been a result of cross-sector fertilization between government, business and not-for-profit organizations which has arisen in order to tackle complex global problems that require sophisticated solutions, for example, climate change. Phills et al. (2008) define social innovation as "a novel solution to a social problem that is more effective, efficient, sustainable, or just, than existing solutions and for which the value created accrues primarily to society as a whole rather than private individuals." Within the broader concept of social innovation exists the phenomenon of "social entrepreneurship" (Ross et al. 2012). Social entrepreneurs "are those who identify and then challenge - with inspiration, creativity, direct action, and courage - an unjust stable state's equilibrium” (Goldsmith 2010,4). Whereas social innovations contribute to the greater good, not all innovations for the greater good are necessarily social. For instance, creative people who post their own art works, music and videos for free online are not doing social innovation, but they are actively contributing to the enrichment of the innovation commons, which are ultimately for the greater good.

Innovations for the commons have grown considerably due to the development of information and communication technologies (e.g. von Hippel 2005). These technologies give rise to new forms of labor organizations and enable people around the globe to pool their working capacities. Recent phenomena such as open source innovation have shown how powerful these new types of organizations are. Open source innovation can be classified into two fundamental categories: open source software and open design. Whereas open source software aims to generate software programs, open design is focused on the development of physical products. Both phenomena can lead to the development of very innovative products that can be highly competitive compared to products that are made by private companies. With the support of specific types of licenses such as GPL, the knowledge generated during these projects, be it in terms of technical drawings, chemical formulae, or software code are fiven for free to the public. Every interested person can download the corresponding materials, use them or further develop them without having to ask for permissions or paying fees. But the improved product design or software code should have the same license as the original one. That is, the developers have to make their work available for free.

The open source software movement is a well-studied phenomenon. In the literature, the question that has bothered researchers very seriously is what brings independent developers to invest their private resources to produce software that is available for free to everyone? These software programmers are dedicating efforts and time to produce a good that falls into the public domain. Von Hippel (2005) recapitulates the reasons that explain the motivation underlying the participation of software developers in open source projects. He mentions that some of the programmers look for reputation in their community, whereas others strive for achieving proficiency and high level of expertise. Another reason is that many developers are also the users of the software and are therefore interested in advancing its performance. The literature on open source software also underlines the importance of intrinsic motivation of software developers, as the real driver behind contributing to open source projects. Intrinsic motivation is opposed to extrinsic motiva- 
tion, which is related to monetary rewards. One stream of literature, however, emphasizes the benefits of extrinsic motivation at the phase of launching open source projects, as people who are originally motivated by external rewards, may totally forget about it, once they get really involved in the project. Thus motivation will be internalized, making contributors working on the project without thinking of the monetary rewards.

Abdelkafi et al. (2010) asked the question, if the open source principles, successfully implemented in the realm of software, are transferable to the physical world. In other words, are there projects that are organized like open source software projects, but aim to develop physical goods? The theoretical analysis of the inherent differences between software and physical goods shows that software has serious advantages; several characteristics of software are conducive to open source development. The authors' case study investigation, however, demonstrate that many "open source" projects have been actually launched in the area of physical products. To distinguish them from open source projects in the realm of software, these projects are referred to as open design projects. Abdelkafi et al. (2010) investigated the solutions developed by open design projects to overcome the barriers due to the inherent characteristics of physical goods. One of the insights of this research is that many projects strive for transforming a development task from the physical to the software world by using programmable hardware. The advantage of this solution is that the performance of the physical product improves, only by using better software.

In addition, to open source and open design projects, innovations for the commons can take the form of open contents. Open content innovations such as Wikipedia are principally different from open source innovation projects. Open content aims to generate and provide content for free on the Internet. Thus it does not initiate a platform for creating collaboratively new knowledge, but rather for sharing and publishing existing knowledge.

Taking the above discussion into account, I define innovations for the greater good, as a combination of social innovations and innovations for the commons. Consequently, the value proposition of the business models for the greater good can be commons or socially oriented. The value proposition is said to be commons-oriented, if it is focused on the development of open source software, open design or open content. In general, commonsorientation means that the product or service-related knowledge is made available to everybody without any restrictions. Thus, the creation of innovations for the commons is largely a matter of license. The social orientation has to do with using entrepreneurial thinking to contribute to solving a specific social problem. From a very broad view, all companies must have social objectives, since they should act ethically, create jobs, and contribute to the improvement of the economy of their regions. But in the context of this paper, the value proposition is said to be socially-oriented, only if the business model tackles a specific social problem from an idealistic viewpoint.

\subsection{The Value Capture out of Innovations for the Greater Good}

Seeking profits should not be regarded as an aspect that is against one's endeavors to serve the greater good. In the realm of social innovations, Ellis $(2010,21)$ notes that "social innovation is not reserved for one particular sector in society. It is found in the public sector, in the civil sector, in the private sector - and in the cross-section between the three. And although social innovation creates social value, it can be used both commercially and non-commercially." Further, she mentions that "hardcore businesspeople have realized that they can increase their profits by incorporating social responsibility as a part of their 
business strategy and hardcore idealists have recognized that the use of market methods gives them the opportunity to create even more social value" (Ellis 2010, 174-175).

Thus, commercial objectives are conducive to the success of projects, and there is nothing wrong, if e.g. social entrepreneurs strive for making money, as profit orientation can have a positive impact on the sustainability of projects. For instance, one study shows that entrepreneurs in general are much more successful when they create their businesses due to their willingness to make money, instead of their sake of independence (Shane 2008).

The value capture is also an important issue when business models are designed around innovations for the commons. For instance, many products that are developed by open design communities are commercialized by profit-oriented companies. In fact, no organization or individual will be ready to produce and distribute such kind of products, if they are not able to make some money out of it. In the realm of open source software, the projects are not for profit, but capture value from the donations of private persons or companies. For instance, IBM supports Linux financially, as it devotes some software programmers to the project (e.g. Economides/Katsamakas 2006). In addition, it should be noted that Linux opened the door for business models which offer complementary services around the software such as installation and maintenance services. In the field of open contents, whereas Wikipedia, the free Internet encyclopedia, is not profit-oriented and provides its services for free, it is reliant on its users to get financial support, so as to be able to continue its operations.

\subsection{A Taxonomy for Business Models for the Greater Good}

Whereas the value proposition refers to an innovation that is either socially or commonsoriented, the value capture refers to the availability or absence of a profit formula driving the business. By combining both dimensions, a matrix with four types of business models for the greater good is obtained. The examples provided in Figure 3 represent open business models, in which openness mostly happens at the level of value creation. In the bottom left quadrant, the business model of the company has a social orientation and is not aimed at the generation of profits. For instance, Ushahidi is a non-profit company that develops free and open source software for information collection, visualization and interactive mapping. It builds tools for democratizing information, increasing transparency and lowering the barriers for individuals to share their stories. Initially, it was developed to map reports of violence in Kenya during the period of post-election at the beginning of $2008 .{ }^{1}$ The Ushahidi website was used to map incidents of violence throughout the country based on reports submitted via the web and mobile phones (Shirky 2008). Subsequently, this website inspired the founders to launch a platform many people can use around the world. In the bottom right quadrant, the business model generates social value, but strives for the generation of profit. 33 needs is a crowdfunding platform, which supports social entrepreneurs in finding investors. Crowdfunding is a new form of finance, which involves individual persons and organizations who contribute with small sums of money to fund new projects (e.g. Botsman/Rogers 2010). 33 needs is a profit-oriented company, as it takes $5 \%$ of the funds from each successfully funded campaign. The upper left quadrant represents business models that are not focused on the achievement of profits, while striving for the generation of products and goods that fall in the public domain. For in-

1 http://ushahidi.com/about-us (Retrieval: 15.5.2012). 
stance, Wikipedia and open source projects are all projects that belong to this category. Finally, the upper right quadrant in the matrix designates the business models of companies that come up with innovations that belong to the commons, but are still profitabilityoriented. In fact, a plethora of open design projects (e.g. Abdelkafi et al. 2010) can be assigned to this category. For instance, Elphel produces and sells high-performance cameras with open designs. Developers deliberately work on the cameras software and hardware and can modify them. Sometimes, applications can emerge out of the work of users the company itself could not think of.

\begin{tabular}{|c|c|c|}
\hline \multirow{2}{*}{$\begin{array}{l}\text { Commons- } \\
\text { orientation } \\
\\
\text { Social } \\
\text { orientation }\end{array}$} & $\begin{array}{l}\text { Non-profit-oriented business } \\
\text { models for the generation of a } \\
\text { commons good } \\
\text { e.g. Wikipedia }\end{array}$ & $\begin{array}{l}\text { Profit-oriented business models } \\
\text { for the generation of a } \\
\text { commons good } \\
\text { e.g. Elphel }\end{array}$ \\
\hline & $\begin{array}{l}\text { Non-profit-oriented business } \\
\text { models for the generation of a } \\
\text { social good or service } \\
\text { e.g. Ushahidi }\end{array}$ & $\begin{array}{l}\text { Profit-oriented business models } \\
\text { for the generation of a social } \\
\text { good or service } \\
\text { e.g. } 33 \text { needs, a Crowdfunding } \\
\text { for social-cause entrepreneurs }\end{array}$ \\
\hline & $\begin{array}{l}\text { Non-Profit } \\
\text { orientation }\end{array}$ & $\begin{array}{c}\text { Profit } \\
\text { orientation }\end{array}$ \\
\hline
\end{tabular}

VALUE CAPTURE

Figure 3: Business model categories for the greater good

\section{The Open School - An Open Business Model for the Greater Good from the Context of Higher Education}

An example of open business models that combines social innovation and innovation for the commons is the open school business model. Recently, some universities have been experimenting with this new model to innovate in higher education. The author himself has been involved in an open school project and could do many experiments to test the applicability and acceptability of this new business model. Open school has emerged out of the idea that universities are currently experiencing the pressing need to be innovative and to create new methods and solutions. Thei objective of open school is to make higher education more attractive, while improving the quality of education. In the following, I explain the reasons why universities need new business models, then define the open school model, and show how it fits into the framework of business models for the greater good. Subsequently, some concrete open school experiments are discussed, and finally a SWOT analysis of this new business model is proposed. This analysis develops the strengths and 
weaknesses of this model, as well as the opportunities and threats that may result if universities implement the model in practice. As a result, I provide a compelling argument how it is possible to make open school a mainstream business model in the future.

\subsection{Why do Universities Need to Change Their Existing Models?}

In the digital age, students want to get more than traditional lectures and look for more flexibility during their studies (Tapscott/Williams 2010). The new opportunities that result from the use of digital technology make it obvious that universities can offer more than they do today. Students have access to online encyclopedias; they can watch the online lectures podcasted by the best universities worldwide; they can be members of social networks and communities to exchange information with their peers. Thus access to knowledge is no longer the problem, as knowledge is available all around a few clicks away. The value that lectures and other traditional modes of teaching created for students in the past, before Web 2.0, seems to be continuously diminishing. And this value will be decreasing, as the capabilities of the Internet improve.

Thus, to improve higher education, new concepts are required. Open school is a promising business model concept that can support this goal. Open school has been introduced in Abdelkafi et al. (2010), and Abdelkafi/Posselt (2011). Open school not only provides some answers to the question how to rethink higher education at universities; it also represents a new mindset of doing the university's business, as it integrates students more actively in the university's daily life.

Open school goes beyond existing paradigms such as open university or open courseware, which focus on freely revealing learning and research materials to users. The open school business model considers students as knowledge creators and active actors in their universities; they are no longer the passive consumers of knowledge. Therefore, in order for the students to become active contributors, the university must provide them with an adequate platform, on which they can interact and perform specific tasks. Although open school can principally be supported by an offline platform, over which students can work collaboratively, an online solution offers much more advantages.

Information technology that supports open source development, online communities, creation of open contents, and idea competition can be used to support open school. When universities embark on an open school business model, they capture ideas from students and solicit their solutions to diverse problems. The variety of activities that can be posted on the platform is basically unlimited. It may range from simple tasks such as idea competitions, aiming to improve university's life conditions, to more complex tasks such as developing innovative learning materials and contributing to research projects (Abdelkafi et al. 2010).

Students can share their ideas, concepts, or drafts to help gradually develop solutions to the problems posted on the platform. In line with the principles of Internet communities and open source innovation, students can work collaboratively, improve the ideas of their peers, and create new ones. In this way, universities have a better access to an intellectual resource, which has been insufficiently exploited so far. They enable their students to act more as an active staff than only to have a passive role. 


\subsection{Why is Open School an Open Business Model for the Greater Good?}

To demonstrate that open school is actually a new business model in higher education, I discuss it from the perspective of the business model framework explained above. In particular, I explain how the open school introduces changes in the business model dimensions: value proposition, value communication, value creation, value delivery, and value capture.

Open school modifies the value proposition in higher education; it enables students to exert more influence on what they are getting from their universities. In the traditional understanding of the university - as a closed system - the value proposition may be to offer students a distinguished education, by providing them with excellent teaching materials, excellent lectures, and good learning atmosphere. In an open school, however, many elements of the value proposition can be modified by the students themselves. For instance, students may be asked to actively generate and improve teaching materials such as lecture slides, or company case studies. Thus the teaching staff may not wait until the course nears its end to ask students for their evaluation of the lecture. The lecturer can get an instant feedback, while providing students the opportunity to actively improve the course materials. Students who think that some contents in the lecture are not clear can make some literature research and find a better way to make the underlying concepts better understandable. In an open school, students can share the new slides and explanations, while submitting concrete suggestions for improvement. After having checked the appropriateness of the new material, the lecturer can integrate them in the lecture documents.

Open school can also lead to the development of new offers that the university may have never provided so far. For instance, what about a mobile phone app that is specifically developed by students to facilitate the start of the academic life for foreign fellow students? As foreign students may have difficulties with the language of the host country, such applications are very helpful and of high value for these students.

In its basic principle, the open school business model does not necessarily call for the use of an Internet platform. With respect to value delivery and value communication, however, the online channel can be extremely useful. For universities to open value delivery, suitable settings are required. For instance, a potential setup is to involve students in teaching, while enabling them to support each other. For a small class of students (e.g. about 50 to 60 students), it is thinkable to divide students into small groups (3 to 5) who are subsequently involved very actively in the discussion of the lecture contents. Let us assume that the course consists of 15 lectures in total ( 90 minutes each) and that 15 groups of four students have been formed. Each group of students gets the responsibility for the contents of one lecture. Thus, right after the teaching staff presents the lecture's contents; the members of the group serve as tutors, answering the questions that their classmates submitt online. To be able to answer these questions, the members of each group have to understand perfectly the contents of the lecture that was assigned to them. On his side, the teaching staff can observe the discussions between students and may evaluate the performance of the single groups with grades. This setup shows how it is possible to make students deliver value to each other. Thus in an open school, it is not only the university, which is responsible for value delivery, but also the students themselves.

For value communication, the open school business model can leverage the potential of network effects and involve students in the communication of value. For instance, the online platform can have interfaces to social networks such as Facebook or Twitter to ach- 
ieve a wide diffusion of the open school value proposition. Students may even recruit friends or students from other universities and involve them in value creation.

In fact, open school is based on value co-creation with students. Students can co-create with three areas of the university: teaching, research, and administration. For instance, students can be involved in research when they work on finding solution to specific problems extracted from big research projects. Students can also be asked to work on the development of software programs according to the principles of open source. In addition, tasks can originate from outside the areas of teaching and research. For example, students can develop a solution that reduces the long waiting times in front of the counters of the university's canteen.

The last dimension deals with value capture. The open school business model can enable universities to leverage additional sources of money, no matter if the university is profit or non-profit-oriented. For example, an open school business model can support technology transfer, by enabling the linkage between university and industry. Instead of going through the technology transfer offices, companies may submit directly their research problems on the open school online platform. Subsequently, research staff and students can work on generating solutions to these problems. When suitable solutions are found, the company pays money to the university, which it can use to fund further research projects. For the students, the open school business model can also represent a source of income. For example, at the university of Erlangen-Nuremberg, the winners of the innovation contest, organized within the scope of the lecture "Basics of E-Business", can win an attendance at a scientific conference, whose fees are completely taken in charge by the university. Furthermore, it is thinkable to provide monetary rewards to students, if they participate successfully in industry projects (Neyer/Abdelkafi, forthcoming).

The above discussion makes it obvious that open school satisfies the criteria of open business models. At the same time, it shows that open school has enormous potential to serve the greater good. When software is developed according to the principles of open source, the open school business model is said to be generating innovations for the commons. But when a mobile phone app is created to help foreign students get a better start in their study programs or when students are provided with a platform to help each other in assimilating course contents, the open school business model has more the social aspect in focus. Consequently, the open school is a good example that shows how a single business model can generate social innovations and innovations for the commons.

\subsection{Examples of Open School Experiments}

Before launching new business models in practice, it is very important to carry out some experiments to evaluate their applicability and viability (Kaplan 2012). This is not only true for business models of private companies, but also for business models for the greater good. I have been involved in many open school experiments at the University of Leipzig where I am teaching innovation management for bachelor and master students. Using the IDEANET-platform of HYVE AG, a Munich-based company, I initiated many innovation contests with my students. Haller et al. (2011) provide many examples that explain how innovation contests can be used to serve the greater good; they cite "The Challenge: future" as an example of global student contest that targets the promotion of sustainability and environment protection. Therefore, innovation contest platforms are well suited to support the implementation of the open school business model. Students have a space for 
online discussions; they can submit ideas around the clock, comment on the ideas of their classmates, evaluate them, generate multiple versions of their own ideas, and upload support materials such as videos or PPT slides (e.g. Bullinger et al. 2010).

In the first innovation contest, organized in the winter semester 2010/2011, I asked my students to develop ideas for the physical products or services they have ever dreamt of, but never found on the marketplace. The setup of this innovation contest was quite complex and described in detail in Abdelkafi (2011). All students have participated in the contest and were motivated. The extrinsic motivation level was very high, since the weight of the student's performance in the innovation contest accounted for $50 \%$ of the final grade. The students' ideas were quite innovative. The best winning idea was the self-cleaning board, which is a white board that can be cleaned automatically without the manual intervention with a wiper.

In the second innovation contest in summer semester 2011, I used a quite different setup from the first one. The task that the students had to work on consisted in developing service ideas that can be offered by students for students. Bachelor and master students have participated in this contest, resulting in a higher level of participation than in the previous contest. In this contest, the extrinsic motivation was important, since $20 \%$ of the final grade depends on the students' performance in the innovation contest. Therefore, all students in the class took part in the contest. The winning idea was the proof-reading service innovation. By means of a one-minute video, the students excellently illustrated the essence of the new service.

During the winter semester 2011/2012, I changed the setting of the contest once again and asked my students to develop new concepts for the university of the future. In contrast to the previous semesters, participation was not obligatory. The students' performance in the contest only accounted for $20 \%$, if it improved the final grade, otherwise it was not included at all. Contrary to my expectations, which were based on arguments related to intrinsic motivation, the level of participation in the contest was not high. Many students were not interested and did not participate in the contest. In addition, the quality of the ideas was not as good as in the previous contests. Therefore, in the contest of the summer semester 2012, grades have been reintroduced as a mechanism to nurture the extrinsic motivation of students. The task for the contest, which is still running at the time of writing, consists in developing innovative mobility concepts for the future.

\subsection{A SWOT Analysis of the Open School Business Model}

During the experiments I did with students, I learned that the open school business model has enormous potential to reinvent how higher education works. Nevertheless, there are many difficulties that can act as barriers against this model to become mainstream. In the following, I summarize the results of my experience with the open school business model in a SWOT analysis, thus capturing the strengths, weaknesses, opportunities, and threats (Figure 4).

The SWOT analysis of the open school business model reveals many strengths and opportunities. An important strength is that it provides access to a large intelligence capacity that has been so far underutilized. By considering them as an active staff, students take a new role in their universities. They can contribute to create new knowledge and solve problems related to the university's daily life. Thus, the open school business model releases the creativity of students (Abdelkafi 2011). In addition, it facilitates the technology 


\begin{tabular}{|c|c|}
\hline $\begin{array}{l}\text { STRENGTHS } \\
\begin{array}{l}\text { - } \\
\text { - }\end{array} \text { Setter leverage of the students` intelligence } \\
\text { university as active knowledge producers at the } \\
\text { - } \quad \text { Students getting rich practical experience } \\
\text { Facilitating the technology transfer between } \\
\text { university and industry } \\
\text { - } \text { Creating new sources for generating revenues } \\
\text { for the university } \\
\text { Releasing students' creativity }\end{array}$ & $\begin{array}{l}\text { WEAKNESSES } \\
\text { - A certain level of investment is required to } \\
\text { buy a web-based platform } \\
\text { - Students and teaching staff may consider the } \\
\text { open school as an additional burden. } \\
\text { - Participation is predominantly due to extrinsic } \\
\text { motivation. }\end{array}$ \\
\hline $\begin{array}{l}\text { OPPORTUNITIES } \\
\text { - } \quad \text { Revolutionizing higher education } \\
\text { - Industry increasingly looking for additional } \\
\text { qualifications and skills that go beyond those } \\
\text { that result from traditional education } \\
\text { - Improving the university's image } \\
\text { - Drawing the interest of students from other } \\
\text { universities to work on exciting tasks }\end{array}$ & $\begin{array}{l}\text { THREATS } \\
\text { - Too stringent intellectual property right laws } \\
\text { - } \quad \text { Students not revealing their ideas because of } \\
\text { their fear that their ideas will be stolen } \\
\text { - No support from side of the university's } \\
\text { administration to enable the implementation of } \\
\text { the students' contributions }\end{array}$ \\
\hline
\end{tabular}

Figure 4: SWOT analysis of the open school business model

transfer between university and industry, while creating new sources for generating revenues.

The open school business model enables the university to leverage new opportunities that are not thinkable within the traditional frame of the university. It has the potential to completely revolutionize higher education. Especially, companies can regard the participation of university graduates in open school activities as a very positive additional qualification, which can influence recruitment decisions. Nowadays, many companies do no longer employ university graduates only on the basis of their personal qualifications and academic degrees. Many companies are using their own assessment centers and let graduates go through many rounds of a long and costly selection process. The participation in open school activities can be a good indicator for the companies that the graduate student has the required qualifications for the job, thus saving the companies the costs and time associated with the assessment process. Consequently, open school can contribute to improving the university's image, and it may attract students from other universities to work on exciting tasks.

Nevertheless, the open school exhibits many weaknesses and threats. As far as weaknesses are concerned, open school requires a certain level of investment, especially to purchase the web-based platform. The problem that can emerge is of financial nature, as the university may not have the required money to afford the platform. In addition, after making this investment, there is no guarantee that students and teaching staff will be welcoming the open school model, as they may consider it an additional burden, beside their usual activities they have to do anyway. As discussed previously, extrinsic motivation is 
important in this regard, as students may not participate, unless they get grades for their participation or monetary rewards.

The threats against the diffusion of the open school business model can be the consequence of too stringent property right laws, preventing the university from freely using students' ideas and contributions. The students themselves can also be reluctant to contribute to open school activities, because they want to keep their ideas for themselves. For instance, a bachelor student who participated in the first contest said that she did not submit product ideas on the platform, since she had a fear that her ideas would be stolen and put in practice. Finally, another threat is the lack of commitment from the side of the university's administration. Students will be highly motivated, if they know that their contributions will be regarded seriously and considered for implementation. Students will exhibit higher motivation, if they know that the concept they will develop for the reduction of waiting times in the canteen will be implemented by the university, if it is good and viable.

Thus, to make open school a mainstream business model in higher education, one has to capitalize on strengths and opportunities, while overcoming weaknesses and dealing adequately with the threats. Most of the weaknesses identified in this section can be easily overcome, if appropriate motivation mechanisms are used to drive students and university's staff to be part of the open school. The financial issue is a problem that may be solved by allocating budget to the platform or by applying for third-party funds. Concerning the threats, they are less controllable than the weaknesses. Especially the property rights issue is a topic that needs further investigation.

\section{Conclusions and Directions for Future Research}

This paper demonstrates that the business model concept is an essential mediator between open innovation and the greater good. In other words, without adequate business models, it is not possible to leverage the benefits of open innovation. Currently, the business model concept is largely discussed in the literature, and there is no single definition for this concept. Because of this, I introduced a new and comprehensive value-focused business model framework, in which business models are defined as the way organizations or individuals communicate, create, deliver, and capture value out of a value proposition; it consists, therefore, of five dimensions. Based on this framework, open business models are introduced as those business models that exhibit some degree of openness with respect to at least one dimension.

Innovations for the greater good are beneficial for society and humanity at large. The value proposition of the business models for the greater good can be socially or commonsoriented, and the value capture depends on the fact, if the organization aims to generate profits or not. The combination of both dimensions: value proposition and value capture give rise to four categories of business models for the greater good, for which concrete examples could be found. In this context, it is worth emphasizing that profit orientation is not conflicting with the idea of serving the greater good. When individuals or organizations strive for making money, the odds of success are much greater.

An example of open business models for the greater good is the open school. Open school introduces a new mindset in higher education, and involves particular changes in the value proposition, communication, creation, delivery, and capture of the university. Many experiments carried out with students show that the open school model has good 
chances to succeed in practice. In addition, by means of a SWOT analysis, the strengths, weaknesses, opportunities, and threats of the model could be identified.

This paper has some limitations. Business models are definitely required in order to serve the greater good, but business models are not enough in order to put a business into action. In the field of management, business models may be thought of as a layer between strategy and operations. Models represent an abstraction, and therefore a business model necessarily exhibits a lower level of detail than operations, which refer to the day-to-day business. Thus, after having conceived a very sophisticated business model, there is still no guarantee of success, as a poor implementation of a good business model will not help really much. For sure, research on business models has still to address this question. Therefore, it is not sufficient to devise good business models; it is also necessary to devise methods that translate business models into concrete operational activities. As far as open school is concerned, whereas past experiments are very promising, it is still unobvious if the model will be successful. Therefore, the release of open school in practice should be planned carefully and thoroughly. Due to the principles, on which open school is based, it is very likely that if this business model is implemented adequately, it will revolutionize higher education.

\section{References}

Abdelkafi, N., et al. (2010): From Open Source in the Digital to the Physical World: A Smooth Transfer?, in: Management Decision, Vol. 47, No. 10, pp. 1610-1632.

Abdelkafi, N. (2011): Towards Open School: How to Organize Innovation Contests with Students, Proceedings of Informatik 2011 - Informtik schafft Communities, 41. Jahrestagung der Gesellschaft für Informatik, 4.10-7.10.2011, Berlin, also available online: http://www.user.tu-berlin.de/komm/CD/html/ws602.html [Retrieval: 15.5.2012].

Abdelkafi, N., et al. (2012): Electric Mobility - What can be Learned from Existing Business Models, Proceedings of the $12^{\text {th }}$ EURAM-Conference, Rotterdam 2012.

Abdelkafi, N./Posselt, T. (2011): The Open School Concept - How to Integrate Students more effectively into the University's Business Life?, Proceedings of the $11^{\text {th }}$ EURAM-Conference, Tallinn 2011.

Bieger, T./Reinhold, S. (2011): Das wertbasierte Geschäftsmodell - Ein aktualisierter Strukturierungsansatz, in: Bieger, T., et al. (Ed.): Innovative Geschäftsmodelle, Berlin/Heidelberg, pp. 13-63.

Botsman, R./Rogers, R. (2010): What's Mine Is Yours: The Rise of Collaborative Consumption, New York.

Bullinger, A., et al. (2010): Community-based innovation contests: Where competition meets cooperation, in: Creativity and Innovation Management, Vol. 19, No. 3, pp. 290-303.

Casadesus-Masanell, R./Ricart, J.E. (2010): From Strategy to Business Models and onto Tactics, in: Long Range Planning, Vol. 43, pp.195-215.

Chesbrough, H. (2003): Open Innovation: The New Imperative for Creating and Profiting from Technology, Boston.

Chesbrough, H. (2006): Open Innovation: A New Paradigm for Understanding Industrial Innovation, in: Chesbrough, H., et al. (Ed.): Open Innovation - Researching a New Paradigm, Oxford/New York, pp. 1-12. 
Chesbrough, H. (2006): Open Business Models - How to Thrive in the New Innovation Landscape, Boston.

Economides, N./Katsamakas, E. (2006): Linux vs. Windows: A Comparison of Application and Platform Innovation for Open Source and Proprietary Software Platforms, in: Bitzer, J./Schröder, P.J.H. (Eds.): The Economics of Open Source Software Development, Amsterdam et al., pp. 207-218.

Ellis, T. (2010): The New Pioneers - Sustainable Business Success through Social Innovation and Social Entrepreneurship, Chichester.

Goldsmith, S. (2010): The Power of Social Innovation - How Civic Entrepreneurs Ignite Community Networks for Good, San Francisco.

Haller, J., et al. (2011): Innovation Contests - An IT-Based Tool for Innovation Management, Business \& Information Systems Engineering, Vol. 2, pp. 103-106, also available online: http:// www.bise-journal.org/pdf/5_37187.pdf [Retrieval: 15.5.2012].

Howe, J. (2008): Crowdsourcing - why the Power of the Crowd is Driving the Future of Business, New York.

Huff, A.S., et al. (2008): Strategic Management - Logic and Action, Hoboken.

Johnson, M.W. (2010): Seizing the White Space, Boston/Massachusetts.

Kaplan, S. (2012): The Business Model Innovation Factory - How to Stay Relevant when the World is Changing, Hoboken.

Lecocq, X., et al. (2006): Le business model, un outil d'analyse stratégique, in: L'Expansion Management Review, Vol. 123, pp. 96-109.

Magretta, J. (2002): Why Business Models Matter, in: Harvard Business Review, Vol. 80, pp. 86-92

Neyer, A-K./Abdelkafi, N. (forthcoming): Educating Open Innovation Ambassdors, in: Huff A., et al. (Eds.): Leading Open Innovation, Cambridge.

Osterwalder, A. (2004): The business model ontology - A proposition in a design science approach, Dissertation 173, University Lausanne, Switzeland, also available online: http://www.hec.unil.ch/ aosterwa/PhD/Osterwalder_PhD_BM_Ontology.pdf [Retrieval: 15.5.2012].

Osterwalder, A./Pigneur, Y. (2010): Business Model Generation, Hoboken.

Phills Jr., J.A., et al. (2008): Rediscovering social innovation, Stanford Social Innovation Review, Vol. 6, No. 4, pp. 34-43, also available online: http://www.ssireview.org/articles/entry/rediscovering_social_innovation [Retrieval: 15.5.2012].

Ramaswamy, V./Gouillart, F. (2010): The Power of Co-Creation, New York et al.

Reichwald, R./Piller, F. (2009): Interaktive Wertschöpfung - Open Innovation, Individualisierung und neue Formen der Arbeitsteilung, 2. Edition, Wiesbaden.

Ross, T., et al. (2012): Bottom-up grassroots innovation in transport: motivations, barriers and enablers, in: Transportation Planning and Technology, Vol. 35, No. 4, pp. 469-489.

Shane, S. (2008): The illusions of entrepreneurship: The costly myths that entrepreneurs, investors, and policy makers live by, London.

Shirky, C. (2008): Here Comes Everybody - The Power of Organizing Without Organizations, New York.

Tapscott, D./Williams, A.D. (2010): Macrowikinomics: Rebooting Business and the World, London.

Toffler, A. (1980): The Third Wave, New York et al. 
Von Hippel, E. (2005): Democratizing Innovation, Cambridge.

Von Hippel, E./von Krogh, G. (2003): Open Source Software and the "Private-Collective" Innovation Model: Issues for Organization Science, in: Organization Science, Vol. 14, No. 2, pp. 209-223.

Nizar Abdelkafi, Dr. rer. pol., is head of the business models and services research group at the Fraunhofer MOEZ in Leipzig as well as lecturer at the Chair for Innovation Management and Innovation Economics at the University of Leipzig.

Address: Fraunhofer-Zentrum MOEZ, Städtisches Kaufhaus Leipzig, Neumarkt 9-19, 04109 Leipzig, Germany, Tel.: +49 (0)341/231039-143, Fax: +49 (0)341/231039-190, EMail: nizar.abdelkafi@moez.fraunhofer.de 